\title{
PEMAKNAAN GENDER PEREMPUAN PEKERJA MEDIA DI JAWA BARAT
}

\author{
Maimon Herawati* \\ Program Studi Jurnalistik Fakultas Ilmu Komunikasi Universitas Padjadjaran
}

\begin{abstract}
ABSTRAK
Keterlibatan perempuan di ranah publik sering berhadapan dengan pandangan bias gender yang lebih menempatkan peran perempuan di ranah domestik. Pekerjaan di media pada umumnya dipandang sebagai pekerjaan laki-laki. Perempuan pekerja media berada dalam dunia yang maskulin. Oleh karena itu konflik peran gender pekerja wartawan di rumah dan kantor menarik untuk diteliti. Penelitian ini menggunakan pendekatan kualitatif dengan menggunakan fenomenologi untuk mengeksplorasi pemaknaan gender perempuan pekerja media di Jawa Barat. Subjek penelitian adalah perempuan pekerja media di Jawa Barat. Teknik pengumpulan data yang digunakan adalah wawancara mendalam, observasi dan studi literatur. Hasil penelitian dianalisis secara kualitatif dan interpretatif. Hasil penelitian menemukan bahwa perempuan pekerja media memaknai dirinya 1) sebagai perempuan memiliki perbedaan dengan laki-laki akan tetapi tidak dimaknai negatif, 2) sebagai perempuan sama dan setara dengan laki-laki, 3) sebagai perempuan diperlakukan adil dalam keluarga dan sekolah, 4) memaknai dirinya lebih kuat atau memiliki kelebihan dibanding laki-laki disekitarnya, 5)memandang tugas mengurus anak adalah tugas perempuan, dan 6)memilih keluar pekerjaan jika terjadi benturan antara pilihan mengasuh anak dengan bekerja .
\end{abstract}

Kata-kata kunci: jurnalis perempuan, Indonesia, gender, media, Jawa Barat

\section{GENDER ROLE UNDERSTANDING OF FEMALE MEDIA PRODUCER OF WEST JAVA}

\begin{abstract}
The involvement of women in public sphere is often met with gender bias which position women in a domestic sphere. Media profession is also deemed as masculine. It is then interesting to examine female media worker of understaning of gender role. This research adopts qualitative approach using phenomenology methods to explore the gender construction of female media worker in West Java. Depth interview, observation, and literature study are employed. Qualitative and interpretative analysing are used. The research shows that female media worker see herself 1) as a women who is different than men, although not in a negative sense, 2) equal as to men, 3) as women she was treated equally at home and school, 4) stronger or better than men around her, 5) responsible for childcare, and 6) will choose to resign from work if there is a conflict between childcare and work.
\end{abstract}

Key words: female journalist, Indonesia, gender, media, West Java

\section{PENDAHULUAN}

Perkembangan media massa di Indonesia meningkat pesat khususnya setelah masa reformasi. Begitu pula pendidikan tinggi komunikasi yang melahirkan banyak sarjana Ilmu Komunikasi. Perempuan terdidik di bidang komunikasi melebihi laki-laki. Sebagai contoh, Fakultas Ilmu Komunikasi, Universitas
Padjadjaran pada 2013 menerima mahasiswa Jurnalistik sebanyak 67 orang, 46 di antaranya perempuan. Peluang perempuan untuk bekerja di media massa dengan demikian terbuka luas.

Permasalahan yang menarik untuk dikaji adalah bagaimana pandangan gender perempuan yang bekerja di media? Hal ini menarik karena secara sosial dan budaya perempuan bekerja di ranah publik apalagi

\footnotetext{
* Korespondensi: Maimon Herawati, S.Sos., M.Litt.. Program Studi Jurnalistik, Fakultas Ilmu Komunikasi Universitas Padjadjaran, Jl. Raya Bandung-Sumedang Km.21.Email: maimonh@gmail.com
} 
dalam hal ini di media yang sangat maskulin memiliki potensi konflik dengan peran perempuan yang dinternalisasikan di ranah domestik. Bagaimana kaum perempuan mengatasi hal tersebut untuk terus bertahan dalam profesinya atau pekerjaannya di ranah publik?

Meningkatnya pendidikan perempuan mulai menggeser pandangan tentang perempuan, karena dia mulai atau sudah diakui memiliki kompetensi yang sama dengan lakilaki untuk berkiprah di ranah publik. Akan tetapi di sisi lain pandangan bahwa ranah domestik adalah sepenuhnya tanggung jawab perempuan umumnya belum berubah. Hal ini menyebabkan perempuan yang berperan di ranah publik memiliki masalah ketika beban mereka di ranah domestik tidak dapat dibagi dengan pasangannya. Oleh karena itu, tidak mengherankan apabila perempuan pekerja khususnya yang bekerja di media harus menyeimbangkan tugas di kantor dengan tugasnya di rumah tangga.

Merujuk pada beberapa penelitian yang telah dilakukan terdapat beberapa masalah terkait peran perempuan di ranah publik dan domestik. Penelitian Miloch menunjukkan adanya kegamangan perempuan pekerja media di Amerika (Miloch 2005). Miloch mencatat, pekerja media senior menasehati juniornya untuk, "Siap memilih antara pekerjaan dan keluarga, sementara pada saat yang sama harus selalu membuktikan dirimu [mampu sebagai pekerja media] lagi dan lagi," dan "siap untuk perjalanan yang panjang dan sulit. Jangan berharap banyak untuk kehidupan sosial atau anak kalau ingin maju di pekerjaan ini." (Miloch 2005, hal. 230)

Penelitian Miloch sejalan dengan penelitian Aldridge yang menemukan fakta bahwa perempuan pekerja media di Kanada memilih untuk tidak memiliki anak sama sekali demi menyeimbangkan tugas rumah tangga dengan tugas di tempat kerjanya (Aldridge 2001). Permasalahan tersebut tidak saja di masyarakat barat, penelitian lain di Hongkong juga menemukan adanya konflik peran yang dianggap menjadi sebab utama perempuan pekerja media Hongkong meninggalkan profesi mereka (Tsui 2011).

Gambaran yang telah diperoleh tentang perempuan yang bekerja media dari beberapa penelitian tentu saja merugikan. Perempuan memiliki kopetensi untuk bekerja di media. Kehadiran perempuan di media sebagai pekerja sangat penting untuk menyeimbangkan sudut pandang yang ditampilkan di media. Oleh karena itu terbatasnya perempuan pekerja media akan mengurangi terpublikasinya sudut pandang atau pemahaman yang mendalam tentang perempuan. Ketimpangan ini tidak saja dapat mempengaruhi pandangan khalayak terkait dengan masalah perempuan akan tetapi juga kebijakan publik yang melibatkan perempuan.

Kekhawatiran akan terbatas atau bahkan berkurangnya perempuan yang bekerja di media cukup beralasan. Dari riset AJI, diketahui bahwa mayoritas perempuan pekerja media di Indonesia adalah perempuan yang berusia di bawah 35 tahun (85\%). Dilihat dari keseluruhan sampel yang diteliti, hanya terdapat $27.5 \%$ perempuan pekerja media yang telah menikah, sisanya (72,5\%) merupakan perempuan lajang (Luviana, 2012, hal.31-32). Berdasarkan data tersebut terlihat adanya kecenderungan bahwa perempuan yang bekerja di media akan berhenti saat dia menikah.

Merujuk pada beberapa penelitian yang terungkap maka dapat diasumsikan bahwa salah satu alasan perempuan pekerja media mundur saat mereka menikah, adalah karena mereka harus bertangung jawab pada ranah domestik atau mengalami kesulitan untuk menyeimbangkan perannya di ranah domestik sebagai ibu rumah tangga dan perannya di ranah publik sebagai perempuan pekerja. Saat perempuan mengalami kesulitan untuk memerankan kedua posisi tersebut, maka yang terjadi adalah posisi perempuan di ranah publik dikorbankan. Artinya perempuan pekerja itu akan mundur baik atas pemahaman mereka terhadap tuntutan yang ditanamkan pada dirinya sebagai perempuan maupun atas desakan lingkungannya.

Permasalahan ini tentu saja akan terus memburuk bila tidak ada upaya untuk menyikapi kondisi tersebut dengan bijak. Oleh karena itu maka perlu dilakukan penelitian terkait dengan fenomena tersebut untuk memahami beberapa pertanyaan yang muncul dan memberi kontribusi untuk menyikapi masalah tersebut dengan bijak dan menjunjung keadilan bagi perempuan dan laki-laki. 
Berdasarkan paparan permasalahan di atas, maka fokus penelitian ini adalah pemaknaan gender perempuan pekerja media di Jawa Barat. Penelitian ini mencoba mengungkapkan bagaimana perempuan pekerja media yang sudah menikah memaknai gendernya sehingga bisa bertahan bekerja di media.

Apabila kita dapat memahami upaya para perempuan yang dapat terus bertahan bekerja di media dengan segala konteksnya, maka kita dapat menjadikan pengalaman mereka sebagai rujukan untuk memberdayakan perempuan lain agar dapat berkiprah di ranah publik khususnya di media walaupun sudah menikah karena sejak lama, perempuan pekerja media telah berperan besar dalam sejarah Indonesia. Pada 1912 Rohana Kudus mendirikan koran perempuan pertama, Sunting Melayu (Djaja, 1980). Bersama perempuan pekerja media lainnya, Rohana menyiarkan berita, artikel, resep makanan, pantun, cerpen, dan iklan. Selain Rohana, ada Ani Idrus (1918-1999) yang mendirikan majalah Seruan Kita pada 1938 (Ahira). Rohana dan Ani telah berperan di media sebelum negara Indonesia merdeka.

Berbeda dengan awal yang hebat di sejarah media, kehadiran perempuan pekerja di media saat ini terbatas. AJI (Aliansi Jurnalis Independen) memiliki 347 anggota perempuan dan itu hanya $18,6 \%$ dari total anggotanya (Luviana, 2012). Luviana menjelaskan tidak ada data valid untuk jumlah perempuan pekerja media di Indonesia. Luviana memperkirakan jumlah perempuan pekerja media sekitar 10\% dari total pekerja. Di antara mereka, hanya 6\% yang menjabat posisi tinggi di media (Luviana, 2012, hal.39).

Apa yang terjadi di Indonesia juga terjadi di berbagai Negara lainnya. Chambers mengatakan, walaupun jumlah perempuan pekerja media bertambah di berbagai belahan dunia, posisi mereka tetap sebagian besarnya di level terbawah organisasi media, yaitu reporter (Chambers et al., 2004). Selain Amerika, penelitian tentang perempuan pekerja media lainnya menunjukkan jumlah perempuan yang ada di posisi puncak organisasi yang tidak representatif (dalam Tsui, 2011). Proporsi perempuan pekerja media cenderung kecil di kelompok usia tua (dalam Tsui, 2011). Nampak sekali ada segregasi vertikal dalam dunia kerja di media terkait dengan pekerja perempuan.

Walby punya penjelasan yang bagus tentang kondisi ini. Dia menulis, sifat partriarki berubah dari partriarki privat menjadi partriarki publik di abad 20. Jika sebelumnya, perempuan didominasi di rumah mereka (oleh ayah, suami), sekarang perempuan dieksploitasi oleh lelaki secara kolektif di ranah publik, seperti ruang kerja, di mana perempuan menghadapi segregasi vertical (Walby, 2002).

Industri media adalah dunia yang dikuasai lelaki. Zoonen yang mengutip Unesco, mengatakan, 'dalam setiap hal, kehadir-an perempuan sangat minim...di "dunia lelaki". Saat perempuan mengalami tekanan partriarki di ruang kerja, perempuan cenderung memutuskan keluar dari pekerjaannya dan mencari pekerjaan lain yang memungkinkan mereka berkembang lebih baik.

Terkait penelitian ini, di Indonesia telah ada beberapa penelitian awalan tentang kendala yang dihadapi jurnalis perempuan Indonesia dalam profesi. Beberapa penelitian tersebut dilakukan oleh Aliansi Jurnalis Independen (AJI), (Luviana 2012) serta Utari dan Nilan (Utari, 2004). AJI melakukan penelitian di lima kota, sedang Utari dan Nilan memilih studi kasus Ilmu Komunikasi di Ilmu Sosial dan Ilmu Politik Fakultas Universitas Sebelas Maret (UNS), Jawa Tengah. Kedua penelitian menunjukkan bahwa perempuan wartawan menghadapi segregasi vertikal dan horizontal dalam profesi. Luviana menggunakan metode penelitian kuantitatif untuk mengetahui keadaan perempuan pekerja media. Luviana dapat menangkap berbagai variabel seperti kepuasan akan gaji dan fasilitas transportasi dari kantor, akan tetapi penelitiannya tidak bisa menjelaskan berbagai alasan akan kepuasan atau ketidakpuasan itu. Penelitian Utari terfokus pada mahasiswa dan lulusan jurusan Ilmu Komunikasi UNS dan keterserapan mereka dalam dunia kerja di media.

Perjuangan perempuan untuk mendapatkan pengakuan akan kesamaan hak dengan lelaki telah tercatat sejak 1870. Marion Talbot dan teman-temannya mencoba masuk Harvard untuk memeroleh pendidikan, tetapi ditolak dengan alasan bahwa kehidupan kampus akan merusak kesehatan perempuan mereka. Inilah awal perjalanan panjang perjuangan kesejajaran feminis. 
Selalu ada tarik menarik antara peran domestik dan publik perempuan di tengah masyarakat. Tuntutan untuk upah yang sama, kesempatan yang sama dan pendidikan yang diadopsi pada Konferensi Pertama Pembebasan Perempuan pada 1970 (Smith, 1990: 194). Dalam tiga dekade terakhir pasar tenaga kerja menunjukkan perkembangan dramatis, yakni masuknya perempuan ke domain yang dianggap eksklusif laki-laki, misalnya media.

Deklarasi Landasan Aksi dan Rencana Strategis Pengarusutamaan Gender di Konferensi Dunia tentang Perempuan PBB pada 1995 adalah dasar dari gerakan perempuan untuk memajukan partisipasi perempuan bidang politik, ekonomi, sosial, dan budaya. Banyak negara telah mengadopsi platform ini ke dalam undang-undang atau kebijakan mereka sehingga perempuan mendapatkan posisi yang lebih kuat.

Adopsi platform tersebut memberikan hasil yang menggembirakan. Di Italia, misalnya dalam 10 tahun terakhir, perempuan menyumbang peningkatan tingkat lapangan kerja,penurunan pengangguran dan peningkatan secara keseluruhan dalam aktivitas produksi. Pada 2003 saja perempuan menyumbang 80 $\%$ dari peningkatan lapangan kerja. Di Asia, seperti Korea, pengadopsian platform dalam Equal Employment Opportunity Act pada 1987 meningkatkan partisipasi perempuan dalam ranah public (Kim , 2007).

Menelisik keadaan tanah air, perempuan Indonesia masih jauh di belakang kemajuan kaum mereka di berbagai tempat. Indeks kesenjangan gender Indonesia adalah yang terburuk di antara negara-negara selatan Asia Timur pada tahun 2000. Mengutip beberapa angka, hampir 40 persen dari pengusaha perempuan Indonesia berpenghasilan kurang dari 100 AUSD per tahun, sementara hanya 8 persen dari pengusaha laki-laki mendapat sebanyak itu (Jurnal Kajian Wanita, 2008).

Gender dimaknai sebagai konstruksi sosial tentang peran laki-laki dan perempuan di masyarakat. Usaha memaparkan ideologi gender yang beroperasi di Indonesia adalah hal yang tidak mudah dan perlu kecermatan untuk memahaminya. Indonesia merupakan bangsa multikultur, yang terdiri dari 740 grup etnis -tiap etnis dengan budaya mereka sendiri-, 583 bahasa, tersebar di 6 pulau besar dan 17,000 pulau kecil. Bangsa ini juga merupakan komunitas muslim terbesar di Dunia (Budiman, 2011).

Indonesia negara yang baru merdeka pada 1945, setelah dijajah Belanda dan Jepang lebih dari 350 tahun. Indonesia negara dunia ketiga yang mencoba mengadopsi globalisasi, tapi pada saat yang bersamaan khawatir terhadap hilangnya tradisi mereka. Salah seorang pengamat menyatakan pandangannya tentang situasi bangsa Indonesia; 'struggling between colonial legacy, the attempt to create consciousness of nationhood, and at the same time, cultural attempt of each ethnic to fashion identities in relation with other, and heavily influence by global hegemony' (van Wichelen, 2010, hal.xvii.)

Dengan demikian tidak mudah menyebutkan satu ideologi gender yang dipakai di Indonesia. Ideologi gender yang ada di Indoensai begitu beragam sesuai dengan keragaman yang dimiliki masyarakatnya, baik dari aspek etnik, keagamaan, maupun ekonomi. Pendekatan paling mungkin ialah dengan memaparkan hal-hal yang memengaruhi ideologi gender yaitu etnisitas dan agama karena 'their own gendered traditions of right and responsibility'(Blackburn, hal. 197).

Indonesia terdiri dari berbagai kelompok etnis. Ideologi gender beragam kelompok ini juga sangat berbeda satu sama lain, misal etnis Minangkabau yang matrilinial sampai ke etnis Batak yang sangat patrilinial. Di antara dua kutub ini, tersebar berbagai etnis sikap budayanya yang beragam terhadap perempuan.

Masyakarat matrilinial memberikan posisi penting pada perempuan dalam menentukan garis keturunan. Perempuan memiliki kuasa pada garis keturunan dan memiliki kontrol akan tanah dan rumah. Tidak itu saja, dalam berbagai hal yang terkait kemasyarakat dan kesukuan, perempuan memiliki hak suara yang penting. Hak ini' lebih tinggi dari sekedar, 'hak berpendapat'. Perempuan memiliki hak suara sama dengan lelaki. Sebelum pemutusan hal-hal terkait adat dalam suku, pendapat perempuan harus ditanyakan lebih dahulu. Contohnya, jika ada keputusan yang tidak disetujui pihak perempuan, keputusan itu tidak berlaku. (Blackwood, 2001) 
Disisilain, perempuan BatakdiSumatera Utrara, tidak memiliki hak kepemilikan pada properti ataupun hak suara di ranah publik. Garis keturunan ditentukan laki-laki dan kelangsungan marga yang diturunkan melalui laki-laki merupakan hal yang sangat penting bagi keberlanjutan marga bagi orang batak. Oleh karena itu anak laki-laki atau kaum lakilaki menjadi sangat penting dan implikasinya perempuan dianggap kurang berharga atau termarjinalkan.

Dua etnis grup di atas berasal dari pulau yang sama, yaitu Sumatera, akan tetapi memiliki ideologi gender yang sangat bertolak belakang. Sementara itu di Indonesia masih banyak kelompok etnis lain yang memiliki kekhasan masingmasing dalam ideologi gender mereka. Masyarakat Bugis, Sulawesi Selatan, misalnya, memiliki pemuka adat yang transgender. Sebagai etnis yang dalam sejarah Indonesia dikenal sebagai pealut ulung, kelompok Etnis ini umumnya tidak menetap di daerah mereka. Mereka menyebar ke berbagai tempat atau pulau di Indonesia bahkan di luar negeri sehingga mengalami interaksi antar etnis. Dengan demikian, pencairan/ pengentalan nilai etnis sangat mungkin terjadi.

Islam agama yang dipeluk sekitar $88 \%$ bangsa Indonesia (Van Wichelen, 2010, hal.112). Sebagian kecil lainnya adalah penganut agama Kristen, Budha, Hindu, Kong Hucu, dan berbagai keyakinan yang bersumber dari adat istiadat leluhur mereka seperti kejawen, sunda wiwitan, dll. Oleh karena itu komunitas Muslim Indonesia selain terbesar di dunia juga berasal dari berbagai etnis dan tersebar di berbagai tempat au pulau dengan cakupan wilayah yang luas.

Nilai dan tradisi etnis memengaruhi perspektif Muslim di Indonesia terhadap hukum Islam. Melihat pada akar pemikiran keislaman bangsa Indonesia, kita mengenal dua organisasi besar yang memiliki pengikut terbanyak yaitu Nadhatul Ulama (NU) dan Muhamadyah. Nahdatul Ulama (NU) secara sejarah diketahui mengambil peran sebagai organisasi Islam yang melakukan penerjemahan hukum Islam atau menggabungkannya kedalam nilai-nilai tradisional. Pimpinan agama yang mereka sebut kyai sangat dikultuskan dan bukan orang yanag dapat mereka pertanyakan pendapatnya. Berseberangan dengan NU, Muhammadiyah mengambil sikap tegas dengan menerjemahkan Islam secara moderat dan terpengaruh pendidikan Barat mereka tidak menjadikan kyai atau pimpinan agama seolah-olah kultus dan memiliki kuasa yang sangat kuat (Pintak, 2011, hal. 189).

Perkembangan perempuan di Indonesia tidak lepas dari keberadaan dua organisasi besar ini maupun organisasi atau partai yang berkembang kemudian. Nadhatul Ulama dan Muhammadiyah memiliki sub organisasi perempuan (underbow) yaitu Aisyiyah (Muhammadiyah) dan Muslimat NU (Nadhatul Ulama). Organisasi Muslim lain yang berbentuk partai dan berkembang sejak reformasi adalah Partai Keadilan Sejahtera (PKS). PKS dalam misinya menggunakan demokrasi dan politik sebagai saluran untuk menyebarkan Islam. Orgainsasi Islam lainnya yang juga berkembang pesat setelah reformasi adalah Hisbutz Tahrir Indonesia (HTI) yang menolak demokrasi dan bercita-cita mendirikan kekhalifahan Islam (Van Wichelen, 2010). Kedua organisasi Islam ini (PKS dan HTI) juga memiliki organisasi perempuan yang aktif di masyakarat.

Selainorganisasi-organisasidiatas,setelah reformasi berkembang pesat pula gerakan neosalafi yang berpendapat interpretasi mereka terhadap Islam adalah yang paling benar dan memilih menegakan nilai Islam menurut pandangannya dengan cara keras. Organisasi berhaluan keras ini diantaranya Front Pembela Islam (FPI). Gerakan Islam lainnya yang memiliki pandangan yang berseberangan dengan kelompok-kelompok Islam lainnya adalah Jaringan Islam Liberal. Dikarenakan grup ini kecil dan bersifat kontroversial maka media termasuk sering meliputnya. Melalui media maka Jaringan Islam Liberal (JIL) mempromosikan penerjemahan Al Qur'an secara liberal. Muslim konservatif banyak yang tidak sepakat dengan JIL bahkan secara tegas atau militan menentang JIL (Van Wichelen, 2010). (Pintak, 2011, hal.188.)

Berbagai kelompok Islam baik yang ada sebelum reformasi atau berkembang setelah reformasi maupun organisasi Islam yang besar atau hanya kelompok kecil dapat dipahami memiliki interpretasi masing-masing yang saling berbeda tentang kesetaraan gender. Sebagian kelompok Islam lebih memberikan 
kebebasan kepada perempuan dalam hubungannya dengan laki-laki dibanding yang lain. Sebagian lainnya justru menjadikan kalangan perempuan khususnya isteri direpresi oleh dominasi suami.

\section{METODE PENELITIAN}

Penelitian ini menggunakan pendekatan kualitatif untuk mengumpulkan dan menganalisis data dengan perspektif konstruktivisme. Sementara metode kualitatif yang digunakan adalah fenomenologi yang bertumpu pada studi tentang pengalaman individu dalam memahami pengetahuan dan motivasi individu terkait dengan pekerjaan atau profesinya.

Metode ini menggunakan teknik pengumpulan data wawancara mendalam sebagai teknik pengumpulan data yang utama selain observasi dan studi literature sebagai teknik pengumpulan data pendukung. Melalui wawancara mendalam digali pemaknaan perempuan pekerja media terkait dengan pekerjaannya, statusnya di dalam keluarga dan juga lingkungan sosialnya. Selain itu melalui wawancara mendalam juga digali pengalaman mereka terkait pekerjaan dan gender di tempat kerja.

Terkait dengan pemilihan informan dalam penelitian kualitatif, Creswell (2007) menyatakan bahwa dalam penelitian kualitatif penentuan informan seharusnya ditentukan dari awal/sebelum penelitian dilaksanakan. Oleh karena itu pemilihan informan dalam penelitian dilakukan secara purposive sesuai dengan karakteristik informan yang disesuaikan dengan kebutuhan penelitian. Karakteristik informan yang ditetapkan adalah pekerja perempuan media yang berstatus sebagai ibu rumah tangga dan memiliki anak atau remaja.

Unit observasi penelitian yang ditetapkan sesuai dengan kebutuhan data penelitian adalah perempuan pekerja media di Bandung, Cirebon, Garut, dan Cimahi. Informan yang terpilih dalam penelitian ini berjumlah 8 informan penelitian.

Pendekatan Torril Moi pada Bourdieu digunakan untuk menganalisa perempuan pekerja media. Pendekatan ini melihat gender perempuan sebagai kapital yang bernilai negatif. Menurut Moi, nilai negatif bisa dinetralkan dengan mengumpulkan berbagai macam jenis kapital yang lain untul mendapatkan legitimasi dalam field. (Moi, 1999, hal. 291). Gender dilihat sebagai variabel sosial dan budaya. Jadi bukan 'perempuan' melawan 'lelaki'. Oleh karena itu, Akan ada banyak tipe maskulinitas dan feminimitas. Pendekatan ini cocok dengan Indonesia karena keberagaman ideologi gender.

\section{HASIL DAN PEMBAHASAN}

Hasil penelitian menunjukkan pemaknaan informan tentang dirinya memengaruhi pembentukan identitas mereka sebagai perempuan di lingkungannya. Para informan memiliki pengalaman yang memberikan modal bagi mereka untuk memahami dirinya sebagai anak perempuan, orang berpendidikan, pekerja, rekan kerja, isteri, menantu, ibu maupun majikan.

Sebagai anak perempuan, salah seorang informan memaknai dirinya merasa sama dengan laki-laki walau tetap memaknai secara fisik berbeda dengan laki-laki. Hal ini diungkapkan informan dalam wawancara sebagai berikut:

"Tidak ada bedanya antara perempuan dan laki-laki. Ibu saya menuntut walaupun saya perempuan harus sekolah tinggi. Waktu kecil saya merasa ada perbedaan secara fisik (dengan anak lakilaki)akan tetapi di rumah diperlakukan sama" (Informan 1)

Dari ungkapan di atas dapat dimaknai bahwa pemaknaan informan terkait perbedaan fisik tidak mempengaruhi pemaknaan informan tentang dirinya dibanding dengan lakilaki ketika dia merasa diperlakukan sama di dalam keluarga atau oleh orangtuanya.

Secara umum masyarakat memang mengkonstruksi laki-laki memiliki kelebihan dari perempuan dalam hal fisik, kepintaran dan keberanian. Hal ini sebenarnya dirasakan oleh perempuan sehingga kadangkala keinginan untuk menjadi atau merasa seperti laki-laki muncul. Hal ini terungkap dalam pengakuan informan yang menyatakan bahwa dia merasa jadi 'laki-laki' karena hal-hal yang dilekatkan orang pada laki-laki dimiliki oleh dia, yaitu kelebihan atau kekuatan fisik (dia memiliki postur yang lebih tinggi dibanding teman- 
temanya), kepintaran dan sikap berani dimiliki oleh dirinya.

"karena badan saya lebih tinggi, (dan) waktu SD selalu juara kelas, tidak pernah merasa 'kurang' di depan lelaki. Ibu saya guru dan memperlakukan saya dan saudara laki-laki saya sama. Ibu disiplin dan menuntut saya kuat, berani. Di tengah teman-teman, saya malah jadi merasa 'lelaki'. (Informan 2)

Merujuk pada temuan di atas terlihat bahwa konstruksi sosial yang memberi penilaian buruk atau melekatkan nilai-nilai yang lebih rendah pada perempuan justru memunculkan kebangaan pada perempuan ketika memiliki keunggulan atau nilainilai yang dilekatkan sebagai milik lakilaki seperti tampilan fisik, keberanian, dan kepintaran. Hal ini tentunya akan berbeda ketika seorang laki-laki memiliki nilai-nilai yang dilekatkan pada perempuan.

Secara umum informan menyatakan bahwa perlakuan yang diterimanya sebagai anak perempuan sama dengan laki-laki. Akan tetapi nilai-nilai patriarki sebenarnya tidak sepenuhnya hilang dalam pemikiran mereka. Hal ini terjadi karena didalam memperlakukan anak-anak perempuan dan laki-laki masih terdapat rujukan nilai-nilai patriarki yang berasal dari budaya atau yang juga dianggap nilai-nilai dari agama, seperti terungkap dalam ungkapan berikut ;

"sama saja. Orang tua cenderung memanjakan. Saya disuruh sekokah setingginya kalau bisa sampai S3. Sebagai istri kalau bisa mandiri dan punya penghasilan sendiri. Ibu saya mendorong saya sekolah untuk aktualisasi diri saya di masyarakat, karena akan berbeda antara ibu lulusan kuliah dengan ibu lulusan SMA. (akan tetapi) yang beda paling nilai. Perempuan tidak boleh pulang malam. Dalam agama juga beda. (Informan 3)

Hal yang senada juga terkait dnegan konstruksi sosial terkait dengan nilai-nilai budaya terhadap perempuan yang terungkap dalam wawancara berikut:

Tidak ada bedanya. Saya besar di Jakarta. Lingkungan sosial (yang membedakan dirinya) mungkin ada....tapi nggak kentara.
Tidak masalah juga jika pulang malam asal jelas urusannya. Oleh orang tua dipaksa sekolah lagi. Bedanya hanya perempuan harus melakukan pekerjaan rumah tangga. (Informan 4)

Secara sadar seluruh informan merasa bahwa sebagai anak perempuan perlakuan yang diperoleh dari orangtuanya terhadap dirinya sebagai anak perempuan sama dengan saudara laki-laki mereka, terutama terkait dengan masalah pendidikan atau peluang untuk mereka bekerja di ranah publik. Akan tetapi tanpa sadar sebenarnya terungkap pula bahwa masih banyak nilai-nilai yang bias gender yang masih diinternalisasikan dalam keluarga terhadap mereka, diantaranya terkait dengan pekerjaan rumah tangga atau penilaian buruk terhadap perempuan yang beraktivitas di malam hari.

Pengalaman para informan tersebut melatarbelakangi pemaknaan mereka ketika mereka menjadi istri, yang di satu pihak merasa bekerja merupakan prestasi, atau sesuatu yang dapat dan harus dilakukan perempuan baik untuk aktualisasi diri atau untuk ekonomi. Akan tetapi disisi lain, informan sebagai perempuan juga memaknai bahwa kewajiban rumah tangga dan nilai-nilai lain yang dilekatkan kepada mereka sebagai perempuan tetap dirasakan dan sadar tidak sadar mempengaruhi pemikiran, sikap dan perilaku mereka sebagai seorang ibu yang bekerja.

Berdasarkan perolehan data yang dihasilkan maka terkait pemaknaan perempuan tentang dirinya, penelitian ini menemukan bahwa para informan umumnya memiliki; 1) pemaknaan bahwa dirinya sebagai perempuan memang memiliki perbedaan dengan lakilaki akan tetapi tidak dimaknai negatif, 2) pemaknaan akan dirinya sebagai perempuan yang sama dan setara bahkan dengan lakilaki, 3) pemaknaan bahwa dirinya sebagai perempuan diperlakukan adil dalam keluarga dan sekolah, dan 4) pemaknaan dirinya lebih kuat atau memiliki kelebihan dibanding lakilaki disekitarnya.

Selain pemaknaan di atas terdapat informan yang memiliki pemaknaan yang bias gender yaitu pemaknaan bahwa "dirinya sebagai perempuan bagaimanapun juga, harus mengerjakan pekerjaan rumah tangga" 
atau pekerjaan rumah tangga suatu pekerjaan yang tidak layak dilakukan laki-laki. Dengan kata lain informan ini memiliki pemaknaan tentang dirinya sebagai perempuan adalah pihak yang paling bertanggung awab atas pekerjaan rumah tangga.

Konsep diri yang tidak berbias gender akan membuat informan tidak merasa 'melanggar' doxanya saat bekerja di ranah publik dan meninggalkan sebagian kewajiban di ranah domestik. Sementara konsep diri yang masih bias gender misalnya memaknai bahwa ketika dia bekerja maka seharusnya dia berperan ganda secara sempurna karena tugas rumah tangga adalah kewajibannya maka dapat menimbulkan rasa bersalah ketika harus membagi waktunya dengan bekerja dan tidak menganggap bahwa di ranah domestikpun mereka layak berbagi dengan pasangannya.

Berdasarkan data yang ditemukan dalam penelitian diketahui terdapat beberapa hal penting yang diidentifikasi sebagai faktor pendukung dan penghambat peran perempuan pekerja media di ranah publik dan domestik.

Pola asuh atau perlakuan keluarga pada perempuan sebaagai anggota keluarga dan lingkungannya menjadi modal bagi perempuan untuk mengenal dirinya diantara orang lain, membentuk identitas dirinya dan memahami perbedaan dirinya sebagai perempuan dalam pandangan masyarakat. Selain itu pola asuh juga memengaruhi pemaknaan mereka akan dirinya.

Sebagian informan mengatakan keluarganya memperlakukan dirinya dan saudara lakilakinya sama dalam hal pendidikan. Akan tetapi walaupun pendidikan tinggi sebagai modal untuk berkiprah di ranah publik diberikan secara sama antara anak perempuan dengan anak laki-laki akan tetapi penekanan bahwa tanggung jawab perempuan di ranah domestik sangat ditekankan. Inilah yang kemudian sering membuat perempuan yang berkiprah di ranah publik merasa bersalah saat meninggalkan ranah domestic (rumahnya), seperti diungkapkan oleh salah seorang informan berikut: "(saya) merasa bersalah. Saya pergi bekerja pagi-pagi jam 7 pagi sebelum anak-anak bangun, dan pulang pukul 10 malam. Keduanya sudah tidur" (Informan 1). Hal yang sama juga diungkapkan oleh informan lain seperti ungkapan berikut; "Saya ingin mengundurkan diri dari pekerjaan setelah (punya) bayi." (Informan 6)

Pekerjaan di dalam rumah umumnya tetap hanya dibebankan pada perempuan, walaupun sebagian orang tua telah membekali anak perempuannya untuk dapat mandiri dalam aspek ekonomi atau mampu bekerja untuk membantu ekonomi keluarga. Beberapa informan dengan tegas menyatakan bahwa alasan ekonomi menjadi hal utama alasan mereka memilih bekerja.

Merujuk pada gambaran di atas maka dapat dikatakan bahwa ada pergeseran pandangan ke arah yang lebih mendukung atau positif untuk meningkatkan peran perempuan di ranah publik. Akan tetapi tampaknya kurang dibarengi dengan tuntutan atau dorongan pada laki-laki agar mampu berperan di rumah. Lelaki belum banyak bertanggung jawab pada ranah domestik.

Oleh karena itu perempuan yang memutuskanbekerjaharusmemilikipendukung yang dapat mengambil alih pekerjaan rumah tangga atau kewajiban yang dibebankan secara sosial terkait dengan tugas mengurus anak dan rumah. Inilah yang menyebabkan dukungan keluarga atau pekerja rumah tangga sangat menentukan kelangsungan profesi perempuan pekerja media.

Kondisi seperti yang digambarkan di atas terungkap dalam penelitian yang menunjukan bahwa alasan utama dua orang informan dapat bertahan dalam profesinya adalah karena mereka berdua dapat menemukan orang yang dapat mereka percaya untuk mengurus anakanak mereka. Informan 1 mengaku bahwa dia memiliki ibu yang dapat berperan sebagai pengasuh utama setiap kali ia dan suaminya meninggalkan rumah. Hal itu juga dimudahkan karena rumahnya dekat dengan rumah ibunya. Dia biasanya menitipkan anak-anak ke rumah ibunya sebelum berangkat untuk bekerja dan menjemput mereka setelah pulang kerja. Jika ibunya sedang sibuk, maka ia dapat meminta bantuan tetangganya sebagai pengasuh anakanak nya.

Kasus lain yang hampir serupa juga diakui oleh Informan 2 yang masih tinggal bersama orang tuanya. Ibunya memutuskan untuk pindah ke rumah putrinya dan membantu merawat cucunya. Ini yang menyebabkan informan 2 merasa dapat bertahan di profesinya atau bekerja sebagai pekerja media. Seorang 
cucu yang diasuh oleh kakek neneknya merupakan sebuah pola asuh yang relatif biasa di masyarakat Indonesia.

Merujuk pada pengalaman informan maka dapat dikatakan bahwa perempuan pekerja di Indonesia sebagian memiliki keuntungan dari kesediaan nenek atau kakek untuk mengasuh cucunya. Situasi itu juga menggambarkan bahwa mengurus anak dalam masyarakat Indonesia tidak berhenti sampai usia mereka dewasa akan tetapi juga membantu mengurus anak dari anaknya (cucu) merupakan kebiasaan orang tua terhadap anaknya, terutama anak perempuan.

Merujuk pada pemikiran Bordieu maka dukungan keluarga tersebut diistilahkan dengan kapital sosial. Pekerja media yang memiliki kapital sosial dapat menjalankan profesinya dengan lebih baik atau sesuai dengan tuntutan profesionalisme. Kapital sosial ini relatif banyak dimiliki masyarakat timur yang masih kental kekerabatannya, termasuk yang dimiliki sebagian masyarakat Indonesia.

Tempat bekerja dan aturan dalam institusi mempengaruhi pengalaman terkait gender perempuan pekerja media. Pemberian insentif atau penghasilan yang tidak mendiskriminasi perempuan sangat dihargai oleh para pekerja media perempuan. Pengaturan waktu kerja yang fleksibel terkait dengan jam kerja atau waktu yang mengharuskan pekerja media di kantor menyenangkan perempuan. Hal inilah yang menjadi salah satu alasan sehingga para pekerja perempuan dapat atau bersedia bertahan di institusi media. Salah seorang informan mengungkapkan tentang proses kerjanya yang tidak harus diselesaikan di kantor dan hal ini disukai informan yang menegaskan bahwa dia suka dengan pekerjaan lapangan.

"Saya sering hanya perlu keluar untuk getter fakta dan data di lapangan selama satu atau dua jam. Saya datang kembali ke rumah dan menulis laporan saya. Saya mengirim mereka ke editor saya dengan handphone ini. Jam kerja (disini) sangat fleksibel sekali”. (Informan 1)

Saat hamil, informan menyatakan bahwa pimpinannya memindahkannya bekerja di kantor. Bekerja di kantor tidak mengurangi profesionalisme para pekerja perempuan karena banyak pekerjaan yang juga harus dikerjakan di kantor.

"Ketika saya hamil, bos saya offerred saya untuk bekerja di kantor. Tahu kan, ada banyak pekerjaan yang harus dilakukan di kantor saja. [Pers] releases. Namun, bekerja di kantor berarti saya tinggal di dalam gedung antara pukul 8 pagi-sampai 16 sore". (Informan 1)

Hal yang sama dikemukakan oleh eva seperti yang diungkapkannya berikut:

"Ketika hamil, saya ditawari untuk pindah ke meja (dengan) beban kerja (lebih) ringan. Jam kantor saya pada waktu itu adalah antara 9-17. Saya tidak meliput malam. Jika ada (peliputan malam hari), teman saya akan menggantikan". (Informan 2)

Merujuk pada situasi di atas maka penempatanapakah seorang bekerjadilapangan atau di kantor, institusi media yang diteliti juga mempertimbangkan kondisi perempuan. Perlakukan istimewa yang dilakukan institusi bukan sesuatu yang harus digugat karena pada dasarnya hal itu justru berbasis keadilan. Tidak adil apabila pekerja perempuan yang hamil kemudian disisihkan atau dianggap tidak profesional karena kehamilannya.

Kehamilan adalah sesuatu yang harus ditanggung oleh perempuan, mau tidak mau itu adalah takdirnya untuk kepentingan bersama baik keluarga maupun masyarakatnya. Oleh karena itu memperlakukan perempuan yang tengah hamil dengan perlakuan yang berbeda justru merupakan keadilan bagi perempuan.

Selain pengaturan dari pimpinan yang memperhitungkan kondisi perempuan dan memperlakukanya secara adil sesuai dengan kondisi yang harus dilaluinya sebagai perempuan, kebebasan yang dimiliki pekerja perempuan untuk berbagi kerja dengan temannya menjadi aspek yang banyak mendorong perempuan bertahan untuk bekerja.

"Saya selalu bisa mengatur dengan teman saya yang akan melakukan apa apa. Bersikap kooperatif dengan satu sama lain. Jika untuk satu hal yang saya tidak bisa melakukan tugas saya, saya meminta bantuan dari teman saya. " (Informan 2) 


\section{SIMPULAN}

Pemaknaan perempuan tentang dirinya terdiri dari beragam peran yaitu sebagai anak perempuan, orang yang berpendidikan, pekerja, isteri, menantu, ibu, maupun majikan. Seluruh peran tersebut dimaknai secara adaptif oleh para informan atau walaupun ada konflik dapat diatasi oleh para informan. Kemampuan informan mensinergikan pemaknaan dirinya dalam berbagai peran disebabkan karena sebagai perempuan pekerja media mereka memiliki pemaknaan bahwa dirinya 1) sebagai perempuan memang memiliki perbedaan dengan laki-laki akan tetapi tidak dimaknai negatif 2) pemaknaan akan dirinya sebagai perempuan yang sama dan setara bahkan dengan laki-laki, 3) pemaknaan bahwa dirinya sebagai perempuan diperlakukan adil dalam keluarga dan sekolah, dan 4) pemaknaan dirinya lebih kuat atau memiliki kelebihan dibanding lakilaki disekitarnya, 5) pemaknaan bahwa tugas mengasuh anak adalah tugas perempuan, 6) sehingga jika terjadi benturan antara mengasuh anak dengan bekerja di kantor, perempuan memilih berhenti dari pekerjaan.

Sebaiknya ada paket informasi tentang perempuan dan pekerjaan di media yang di siapkan untuk keluarga perempuan pekerja media. Seringkali ketidaktahuan akan dunia media ini menimbulkan resistensi keluarga pada profesi wartawan. Institusi pendidikan kejurnalistikan semestinya memasukkan materi gender dan media dalam kurikulumnya. Hal ini penting untuk membangun kesadaran akan pentingnya kehadiran perempuan dalam profesi kejurnalistikan dan sekaligus menyiapkan perempuan calon pekerja media dengan tantangan berbasis gender yang akan dia hadapi di dunia kerja. Institusi media perlu memperjelas hak-hak berbasis gender perempuan pekerja media yang disiapkan sehingga perempuan pekerja media memiliki pilihan yang jelas dalam karirnya.

\section{DAFTAR PUSTAKA}

Ahira, A. "Tokoh wanita yang menginspirasi (Inspiring Women)." Retrieved 9/10/ 2011, 2011, from http://www.anneahira. com/tokoh-wanita.htm.
Aldridge, M. (2001). "Lost expectation? Women journalists and the fall-out from the 'Toronto newspaper war'." Media, Culture \& Society23: 607-624.

Blackburn, S. (1999). "Women and citizenship in Indonesia." Australian Journal of Political Science34(2): 189-204.

Blackwood, E. (2001). "Representing women: The politics of Minangkabau adat writings." Journal of Asian Studies60(1): 125-149.

Budiman, M. (2011). "The middle class and morality politics in the envisioning of the nation in post-Suharto Indonesia." Inter-Asia Cultural Studies12(4): 482501.

Chambers, D., et al. (2004). Women and journalism. London; New York, Rout ledge.

Creswell, J.W., (2007) Qualitative Inquiry and Research Design: Choosing among Five Approaches, London, SAGE Publication,

Djaja, T. (1980). Rohana Kudus Srikandi Indonesia, Riwayat Hidup dan Perjuangannya (Rohana Kudus, Indonesian Female Fighter, Her Life and Struggle).

Hesmondhalgh, D. (2006). "Bourdieu, the media and cultural production." Media, Culture and Society28(2): 211-231.

Kim, K. H. (2006). "Obstacles to the success of female journalists in Korea." Media, Culture and Society28(1): 123$141+145$.

Luviana (2012). Jejak Jurnalis Perempuan Pemetaan kondisi kerja jurnalis perempuan di Indonesia (Indonesian Female Journalist, Their Working Condition). Jakarta, Aliansi Jurnalis Independen.

Miloch, K. S. (2005). "The current state of women print journalists: an analysis of the status and careers of females in newspapers aports department." A Global Journa15: 219-232.

Moi, T. (1991). "Appropriating Bourdieu: Feminist Theory and Pierre Bourdieu's Sociology of Culture." New Literary History42. 
Moi, T. (1999). What is a woman? and other essays. Oxford, Oxford University Press.

Pintak, L. S., B (2011). "The mission of Indonesian Journalism: balancing democracy, development, and Islamic values." International Journal of Press/Politics16: 185-209.

Smith-Hefner, N. J. (2009). "Language shift, gender, and ideologies of modernity in Central Java, Indonesia." Journal of Linguistic Anthropology19(1): 55-77.

Tsui, C. Y. S. L., Francis L F (2011). "Trajectories of women journalists' careers in Hong Kong." Journalism Studies 13(3): 370-385.
Utari, P., Nilan, P. (2004). "The lucky few: female graduate of communication studies in the Indonesian media industry." Asia Pacific Media Educator15: 63-80.

van Wichelen, S. (2010). Religion, Politics and Gender in Indonesia : Disputing the Muslim Body, Taylor and Francis.

Walby, S. (2002). Gender and the New Economy: Regulation or deregulation? Lancaster, Department of Sociology, Lancaster University: 29. 